\title{
Comentários sobre o Projeto FLORAM: primeiros documentos
}

\section{RUI FERNANDO ROMERO MONTEIRO*}

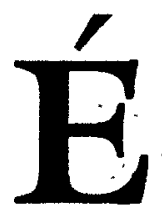

sempre muito louvável a preocupaçăo e atençáo dispensada ao estabelecimento de um plano nacional de reflorestamento utilizando critérios múltiplos e com funçóes diversificadas, nomeadamente com a implantação de fitomassa, reflorestamento ecológico, recuperaçáo de éspaços para silvicultura de fins múltiplos, estabelecimento de reservas de matéria-prima para posterior utilizaçáo racionalizada.

E, para o Brasil, país de dimensáo continental, onde, nas últimas décadas se tém assistido a uma destruiçăo progressiva e contínua das florestas naturais, um plano como o dos autores adquire um aspecto prioritário, mesmo sem levar em conta outras facetas de extrema importância como o efeito estufa, que também foi oportunamente considerado:

Foi, certamente pela cónjugaçằo dos motivos anteriormente referidos, que um grupo de especialistas de elevado nível científico, merecedores de todo o crédito e realistas, resolveu chamar a atençáo para a elaboração de uma política nacional correta de florestas.

Além dos prejuízos ecológicos causados pela destruição das florestas naturais, com efeitos nocivos sobre a conservaçáo do solo, erosáo, diminuiçáo da água infiltrada no solo e conseqüente diminuiçáo ou mesmo seca dos mananciais hídricos, extinção de alguns animais da fauna silvestre pela destruiçăo progressiva do seu habitat natural, etc., . há ainda o aspecto muito importante de que as florestas contribuem para a fixação do carbono do ar atmosférico; diminuindo assim a carga de poluiçăo, contribuindo para atenuar ou mesmo controlar o efeito

* Rui Fernando Romero Monteiro é gerente de pesquisa da Klabin (Lagoa - Monte Alegre). 
estufa, resultante principalmente de emissóes de $\mathrm{CO}_{2}$ provenientes da queima dos combustíveis fósseis.

Ao longo dos textos, nota-se a preocupaçáo constante de considerar a realidade brasileira, evitando atingir áreas agrícolas produtivas, aconselhando a exigência de estudos de previsão de impactos ao nível da dinâmica fisiográfica e ccológica e em termos das consequiências econômicas e sociais de cada projeto, porque são do parecer de que cada caso é um caso e, portanto, exigindo propostas diferenciadas de reflorestamento, contemplando as atividades econômicas $e$ aspectos paisagísticos e ecológicos.

Como dizem os autores, $\mathrm{e} \mathrm{bem,} \mathrm{o} \mathrm{Brasil} \mathrm{é} \mathrm{um} \mathrm{dos} \mathrm{poucos} \mathrm{países} \mathrm{do}$ mundo que possui dimensóes espaciais para desenvolver um plano global de reflorestamento de grande escala, sem prejuízo de todas as outras atividades.

Excluem, como seria de se prever, por razóes óbvias, as regióes dotadas de menos de $850 \mathrm{~mm}$ de precipitação anual e que se situam principalmente nos sertóes do Nordeste, mas sugerem o enriquecimento das florestas de galeria e o reflorestamento das encostas e interflúvios das colinas sertanejas com espécies de utilização múltipla, o que nos parece absolutamente correto e muito realista para aquela zona. Contudo, em viagem rópida feita em fevereiro passado, no limite dos Estados de Pernambuco com o da Paraíba, mais propriamente no Município do Umbuzeiro, chamou-nos a atençáo o acidentado da zona, admitindo que a construçáo de pequenas barragens de terra, em pontos estratégicos, poderiam armazenar a água das chuvas (de 800 a $900 \mathrm{~mm}$ anuais), que serviria para irrigar culturas florestais ou fruticolas de rendimento, a serem instaladas nas proximidades.

A idéia de realizaçáo de reflorestamentos corretivos, reflorestamentos industriais e de reflorestamentos mistos parece-nos correta, conjugando os princípios conservacionistas com os econômicos, porque não poderemos esquecer este fator tão importante na vida atual.

Além do impacto direto sobre o meio ambiente, haveria ainda os ocasionados sobre a economia, nomeadamente mais madeira para celulose, serraria, construçăo civil, diminuição da sobrecarga nas matas nativas, metanol, carvão vegetal, etc. 
Em todos os trabalhos, nota-se a preocupação de respeitar os princípios ecológicos de caráter global e as características ecológicas regionais, fator que considero de extrema importância.

Resumindo, somos do parecer de que se trata de um estudo de muito interesse, não só em nível nacional mas também mundial, que deveria ter seguimento, concretizando as idéias expostas e defendidas nos textos, tornando assim o Brasil um líder na política de reflorestamento ecológico-econômico em nível internacional.

Contudo, terá de ser detalhado para cada uma das regióes do país, considerando as realidades locais. 